

\title{
BEYOND CORPORATISM A CONFIGURATIONAL THEORY OF POLICY CONCERTATION
}

\author{
Hugh Compston \\ School of European Studies, Cardiff University, UK \\ Post-print: article as accepted for publication in \\ European Journal of Political Research, 42, 2003: 809-831
}

\begin{abstract}
Policy concertation, defined as making policy by means of agreements struck between government officials and representatives of employer associations and trade unions, is a major policy style in Western Europe. This article seeks to explain the political dynamics of policy concertation in terms of the varying configurations of three variables: perceived problems, the degree of shared economic understanding among the participants, and the perceived implementation capacity of the participants. It is found that the incidence of broad policy concertation over the 20th century in nine West European countries can be almost completely explained in terms of this configurational theory.
\end{abstract}

Key words: policy, concertation, corporatism, Europe, employers, trade unions 


\section{INTRODUCTION}

Although the idea of employers and unions participating in the making of public policy sounds strange to British ears, elsewhere in Western Europe public policy is often made by means of agreements struck between government officials and representatives of employer associations and trade unions. This practice, which can be termed 'policy concertation' to distinguish it from the more pluralist policy-making characteristic of Britain and other Anglo-Saxon countries, is significant because it affects the content of public policy and therefore the shape of the society we live in. Because decisions are taken by agreement, each participant has a power of veto and is therefore guaranteed influence over the decision. This rules out policy decisions that are unacceptable to employers or trade unions. It also leads governments to introduce policies that they would not otherwise have introduced, in exchange for concessions from employers and unions. In certain cases, the political exchange of policy concertation may render feasible policy options not previously open to the government, such as expansionary economic policies dependent on wage restraint.

Policy concertation in Western Europe during the 1990s included social pacts, agreements struck within the regular state policy-making apparatus between representatives of business, labour and the state, and the implementation by the state of bipartite employer-union agreements. It is most common in the fields of employment and social policy, but in some countries encompasses significant areas of economic policy as well. This broad policy concertation has been associated historically with countries such as Austria, with its Social Partnership, as well as with the Netherlands and Sweden, but the breadth of policy areas covered by policy concertation also varies over time: during the 1990s broad policy concertation was still characteristic of Austria, for example, but had ceased to exist in the Netherlands and Sweden while becoming established in Ireland and Italy (Table 1).

Why does the range of public policy codetermined by policy concertation vary between countries and over time? The purpose of this article is to answer this question. ${ }^{1}$

My starting point is the limited success of theories that use a distinctive corporatist logic to explain the incidence of broad policy concertation in recent years. Not all corporatist theories are devoted to explaining policy concertation, of course. Some seek to explain phenomena such as economic policy and economic outcomes (eg Cameron 1984, Crepaz 1992, Woldendorp 1997), while others focus on explicating corporatism as a state of affairs (eg Lijphart and Crepaz 1991, Keman and Pennings 1995, Siaroff 1999). And those theories that are designed to explain policy concertation often use different terms to refer to it, including the term 'corporatism' itself (eg Lehmbruch 1979, Woldendorp 1997). 
Table 1. Policy Concertation in Western Europe, 1990-1997

\begin{tabular}{|c|c|}
\hline Country & Policy areas covered \\
\hline \multicolumn{2}{|r|}{ Wide-concertation countries with frequent concertation } \\
\hline Austria & $\begin{array}{l}\text { Social policy, fiscal policy, monetary policy, investment policy, industrial policy, } \\
\text { social welfare, labour law, job-creation and training, employment, EU-issues }\end{array}$ \\
\hline \multicolumn{2}{|r|}{ Wide-concertation countries with sporadic concertation } \\
\hline Ireland & $\begin{array}{l}\text { Overall macro-economic policy strategy, social welfare, government spending in } \\
\text { general, employment policy including active labour market policy, regional policy }\end{array}$ \\
\hline \multicolumn{2}{|r|}{ Medium-concertation countries with sporadic concertation } \\
\hline Italy & Taxation, expenditure (especially pensions), labour law \\
\hline \multicolumn{2}{|r|}{ Narrow-concertation countries with frequent concertation } \\
\hline Netherlands & Social security, employment policy \\
\hline Sweden & Many sectors until 1992 , then restricted to labour market policy and pensions \\
\hline Germany & Social insurance, labour law, health, reconstruction of the East \\
\hline \multicolumn{2}{|r|}{ Narrow-concertation countries with sporadic concertation } \\
\hline Spain & Employment law and social security \\
\hline France & Employment law and social security \\
\hline \multicolumn{2}{|r|}{ Non-concertation countries } \\
\hline Britain & None \\
\hline
\end{tabular}

Source: Berger and Compston 2002, political country chapters.

Arguably the most influential theory of policy concertation that does utilise a corporatist logic of explanation starts with the proposition that the existence of corporatist systems of interest intermediation in Schmitter's original sense (Schmitter 1979: 13) means that the organisations involved can no longer externalise the economic costs of their actions. If a trade union in a single industry makes excessive wage claims, it may be possible for employers in that industry to pass these on in the form of higher prices to the rest of society, but if a union movement that encompasses most of a nation's workforce makes excessive wage claims, the resultant price rises hit everyone, including union members. For this reason, encompassing union movements are expected to be more open to negotiating wage restraint than smaller or divided movements, which encourages governments to enter policy concertation with the intent of offering policy concessions in exchange 
for wage restraint (Calmfors 1993, Olson 1982). Corporatism is also expected to facilitate negotiations by limiting the number of participants and by giving to leaders of trade union confederations and employer peak associations the ability to make the binding commitments on behalf of their members that are essential if political exchange is to take place on a continuing basis (Lehmbruch 1979: 167-168, Slomp 1992: 163, Crouch 1993: 54-55, 289).

The problem with this model is that it fails to account for the incidence of broad policy concertation in Western Europe in the 1990s. Although it can explain the persistence of broad policy concertation in Austria, where the compulsory Chamber system is as close to an ideal-type corporatist system as exists in Western Europe, it cannot explain its rise in Ireland, where the distribution of power within employer associations and trade unions is relatively decentralised, or its resurgence in Italy, where employer associations and trade union confederations are institutionally divided.

There are a number of other theories of policy concertation that utilise conceptions of corporatism as explanatory variables, but these generally go beyond the corporatist logic of explanation to include other explanatory variables as well. A number of such variables have been cited in the political economy literature. These include the postwar emergence of a willingness on the part of governments to trade policy concessions for certain commitments by employers and/or trade unions due to the postwar extension of the role of government in managing the economy, labour party participation in government, economic openness, consociationalism, economic consensus, egalitarian political cultures, degree of societal support, the relationship of organised groups to modernisation in previous centuries, and the extensive institutionalisation of contacts between employers, trade unions and the state (for a review of these theories see Compston 1998, 2002).

Rather than criticising these theories, a number of which have considerable explanatory power, what I wish to do here is to offer a new theory of policy concertation that also goes beyond the logic of corporatism by utilising different independent variables and a different logic of explanation, a theory that provides a parsimonious explanation of the incidence of broad policy concertation since 1945 that is at least as compelling as the accounts offered by existing theories. This configurational theory explains broad policy concertation in terms of the changing configurations of values of just three variables: the nature of contemporary problems as perceived by the government; the degree of preexistent shared understanding of the aims and mechanisms of economic policy among governments, employers and unions; and expectations about the likelihood that the prospective participants will implement their sides of any agreements reached.

The first part of the article is devoted to describing this configurational theory and how it works. The second part uses the findings of a major international study of policy concertation to illustrate how the political dynamics of broad policy concertation in Western Europe since 1945 can be almost completely accounted for in terms of the shifting configurations of values of the three explanatory variables.

\section{A CONFIGURATIONAL MODEL OF POLICY CONCERTATION}

The model of policy concertation set out below is inspired by John Kingdon's theory of agendasetting, in which items are seen as coming up for decision when simultaneously a compelling problem is recognised, a solution in the form of a technically and politically feasible policy proposal is available, political change makes politicians receptive, and potential constraints are not too severe (Kingdon 1995). Applying Kingdon's approach to a different dependent variable results in a different theory, but the logic is the same in that both posit that the value of the dependent variable is determined by the coincidence in time of specific configurations of events and conditions. 
The essence of the configurational theory is as follows. Existing modes of policy-making tend to persist unless challenged by a serious problem with which they cannot cope. Where this problem is perceived to be one that arguably could be solved by policy concertation, there will be pressure to introduce this new mode of policy-making, but policy concertation will only occur in practice if at the same time there is a certain degree of pre-existent shared understanding of the aims and mechanisms of economic policy, and the prospective participants are perceived to be reasonably likely to implement their sides of any agreements reached. This explanatory logic can be extended to identify the conditions under which policy concertation is prevented from taking place or, once established, either persists over time or is terminated.

In this section, policy concertation - the dependent variable - is given its operational definition, the three key independent variables are described, and the logic and predictions of the theory are set out in detail.

\section{Dependent variable}

The term 'policy concertation' is defined for analytical purposes as national-level discussions between government representatives and representatives of peak employer and/or trade union confederations that lead to agreements on public policy, that is, to government commitments to adopt particular policies, as opposed to discussions that do not lead to such commitments: the focus is on codetermination of public policy, as opposed to mere consultation. More specifically, the object of interest is policy concertation over a broad range of public policy, defined as concertation that covers a broader range of public policy than its core areas of employment and social policy.

Broad policy concertation thus defined takes four main forms: decision by agreement within government committees; formal tripartite or government-union agreements such as social pacts; informal agreements; and the implementation by the state of bipartite employer-union agreements. Incomes policies are included insofar as they include government commitments on public policy.

\section{Independent variables}

The three key explanatory variables are perceived problems, the degree of pre-existent shared economic understanding among policy actors, and the perceived likelihood of implementation. All of these vary between countries and over time. Although I do not wish to deny the existence of relevant causal variables other than these, the theory to be tested implies that all other causal variables are either relatively unimportant, fit into the model as intervening variables, or operate through the three proximate causal variables specified by the configurational theory, on the rationale that the incidence of broad policy concertation can be adequately explained without reference to any of them.

\section{Perceived problems}

The first proposition is that the spur for governments to consider extending policy concertation to new areas is the appearance of problems with which existing modes of policy-making are not coping adequately, especially economic problems. The main economic difficulty that is hypothesised to lead governments to contemplate policy concertation is inflation where the government sees this as being at least partly fuelled by wage rises, on the grounds that concern to control wages leads governments to consider offering policy concessions in exchange for wage restraint. Although economists always worry about inflation, the extent to which it is seen by governments as a pressing problem varies. Inflation may be perceived as an urgent problem because it is high in an absolute sense, because it is high relative to other countries even though low in absolute terms (the competitiveness criterion), or 
because its salience is increased by the presence of other economic problems, such as the need for postwar reconstruction.

Because it is perceptions of the economy that are important here, and governments at different times and places may have different perceptions of the extent to which a given objective state of economic affairs constitutes a problem, the relevant indicator of economic difficulties is not an objective measure, such as the actual rate of inflation, but an indicator of perceptions of the seriousness of economic problems. This is provided by the evaluations of country experts.

\section{Shared economic understanding}

The second proposition of the configurational theory is that policy concertation is facilitated by a certain degree of pre-existent shared understanding among the government, employers and trade unions about the general aims and mechanisms of economic policy (as distinct from the specifics of economic policy). It is difficult to specify all the aspects of economic policy on which this preexistent shared economic understanding is necessary, especially since this may vary from time to time and from country to country, but two minimum criteria can be readily identified.

First, all political actors must accept capitalism. If trade unions or socialist governments are actively trying to overthrow the capitalist system, sustained policy concertation with employers would not be expected to take place. This means that where there are genuinely socialist or communist governments or unions, broad policy concertation would not be expected to take place.

Second, all political actors must accept the legitimacy of trade unions and collective bargaining. If employers or governments do not, then not only would it be difficult to obtain the wage restraint often desired by governments and employers in exchange for policy concessions, since the coordination of wage rises via collective bargaining would be rendered impossible, but in addition the degree of hostility and distrust between employers and unions would be likely to prevent agreement anyway. This means that broad policy concertation is not expected to take place where employers or governments hold radical right-wing views of either the liberal or authoritarian variety.

Beyond these minimum criteria, concertation on economic policy is expected to be more likely where all political actors, including unions, agree in principle that wage restraint is desirable for economic reasons. Other relevant factors include the extent to which all actors, including unions, subscribe to a philosophy of low inflation and international competitiveness, as distinct from mere acceptance of capitalism, and how tolerant employers are of economic planning, which is often of interest to unions and left-of-centre governments.

Precise measurement of the degree of shared understanding of the aims and mechanisms of economic policy, and how it varies over time, is difficult. The measure used in this article is provided by the evaluations of country experts.

\section{Perceived likelihood of implementation}

The final provision of the configurational theory is that broad policy concertation will only take place if participants believe that their counterparts are reasonably likely to implement their sides of any agreements reached, as otherwise confidence in the efficacy of these agreements will be undermined and policy actors will refuse to take part. It is here that corporatist theory is relevant, as implementation of promises would be expected to be easier where employer associations and trade union confederations are large, centralised and disciplined, and where collective bargaining is coordinated, preferably on a national basis. 
Ultimately, however, perceptions of future implementation are determined not only by these structural factors but also by more contingent factors, such as whether previous agreements were implemented properly and the degree of trust between leaders. For this reason the appropriate indicator of perceived implementation capacity is not organisational structure but expert evaluation of the opinions of the relevant policy actors at the time.

\section{Logic and predictions}

The incidence of broad policy concertation is hypothesised to be a function of the configuration of values of the three variables of the configurational theory. Four possible states of being for broad policy concertation can be distinguished: creation, persistence having been created earlier, termination, and non-existence. Each of these conditions can be explained in terms of one or more configurations of the three explanatory variables. The resulting causal hypotheses are as follows:

1. The creation of broad policy concertation is caused by the combination of (1) the recognition of a serious relevant problem; (2) considerable pre-existent agreement on the aims and mechanisms of economic policy; and (3) the perception that prospective participants are reasonably likely to implement their sides of agreements.

2. The persistence of broad policy concertation is caused by the combination of (1) the solution or disappearance of the problem it was designed to solve where it is feared that an end to concertation might lead to its reappearance; (2) the continuation of a considerable degree of agreement on economic policy; and (3) a continuing perception that prospective participants will implement their sides of agreements, based at least in part on their record in implementing previous agreements.

3. The termination of broad policy concertation is caused by one or more of the following: (1) the continued existence of the original relevant problem or the appearance of another serious relevant problem (since both these instances imply policy failure); (2) the emergence of serious disagreements on economic policy; or (3) a perception, possibly based on previous implementation failures, that participants are not likely to implement their sides of future agreements.

4. The non-existence of broad policy concertation is caused by one or more of the following: (1) the lack of a serious relevant problem; (2) significant disagreement on economic policy; or (3) a perception that participants are not likely to implement their sides of agreements.

It is important to note here that specification of the configurational model as a causal model means not only that it must be based on a plausible causal account, namely that the existence of relevant problems will lead to pressure to introduce policy concertation but that policy concertation will only occur in practice if there is also a degree of shared economic understanding and a perception that prospective participants will implement their sides of any agreements reached, but also that changes in the dependent variable - the creation or termination of broad policy concertation - must be preceded by changes in the configurations of independent variables.

\section{THE CONFIGURATIONAL MODEL APPLIED}

Aristotle pointed out long ago that investigators can only expect to reach the degree of precision appropriate to the subject matter at hand. In this case precision is limited by difficulties in accurately measuring the relevant variables. For example, there may be secret agreements between governments, employers and unions about which researchers know nothing. Similarly, it is difficult

to identify exactly when governments see problems as being relevant and significant. It is also difficult to determine exactly how much economic agreement constitutes a significant degree of economic agreement, and the extent to which actors believe that implementation of agreements is likely. 
The best that can be done in these circumstances is to rely upon the evaluations of country experts, on the basis that such experts have some idea even if it is not completely accurate. For this reason the empirical findings on which this study is based must be interpreted as giving us a somewhat fuzzy picture of the real situation, analogous to a driver's view of the road ahead through a wet windscreen. To reject this degree of precision as being inadequate is to reject this type of investigation altogether, along with a great deal of other mainstream social science research.

To evaluate the explanatory power of the configurational theory, the postwar history of the incidence of broad policy concertation in 9 West European countries was examined to determine the extent to which it is consistent with the predictions of the theory concerning the incidence of the causal factors specified by the theory. The remainder of this article sets out the findings of this examination in the form of a brief history of broad policy concertation and its correlates in the nine countries between 1945 and 1997. The countries covered are Austria, Britain, France, Germany, Ireland, Italy, the Netherlands, Spain (after the return of democracy in 1975) and Sweden.

This history is based mainly on the relevant chapters of the volume that sets out the results of the international study of policy concertation mentioned earlier, plus subsequent consultations with their authors (Berger and Compston 2002) ${ }^{2}$, supplemented by information from other sources where indicated in the text. Although the study itself deals with the entire $20^{\text {th }}$ century up to 1997 , for reasons of space, clarity and contemporary relevance the analysis here is restricted to the postwar period 1945-1997.

The policy concertation volume includes, for each country, a historical study of the period up to 1990 and a political study of the period since 1990, each carried out by one or more country experts. Although these country studies were not undertaken for the specific purpose of testing the configurational theory, they do employ the same definition of policy concertation as that used here and reveal a great deal about the incidence of policy concertation over the course of the $20^{\text {th }}$ century. They also provide causal analyses that include information about the causal factors posited by the configurational theory. Although these analyses often cite other factors as being causally relevant in addition to (or instead of) those examined here, for the purposes of this analysis these other factors are disregarded, as we are testing whether the incidence of broad policy concertation can be adequately explained without reference to them.

Where the authors of country studies do not mention the hypothesised causal factors, their values (null values) are assumed for the purposes of this analysis to be as follows. Where no problem is mentioned, it is assumed that no serious relevant problem exists. Where the degree of shared economic understanding between the political actors is not mentioned, it is assumed that this remains unchanged from previous periods. Where implementation problems are not mentioned, it is assumed that participants expect that others are reasonably likely to implement their sides of any agreements reached.

The policy concertation study as a whole shows that in terms of the frequency, breadth and duration of national-level policy concertation during the period 1945-1997, the nine countries surveyed can be classified into three groups: high concertation countries (Austria, the Netherlands and Sweden), medium concertation countries (Britain, Ireland, Italy and Spain), and low concertation countries (France and Germany), as detailed in Table 2. Readers should bear in mind here that policy concertation means the co-determination of public policy and not consultation, however extensive or influential consultation has been in countries such as Germany. 
Table 2. Incidence of Policy Concertation 1945-1997

\begin{tabular}{|c|c|}
\hline Country & Significant episodes of policy concertation \\
\hline \multicolumn{2}{|r|}{ High concertation countries } \\
\hline Austria & Social Partnership from 1950s \\
\hline Sweden & $\begin{array}{l}\text { Combination of top-level negotiations, representation on executive agencies and } \\
\text { participation in policy-making commissions 1930s to } 1992\end{array}$ \\
\hline Netherlands & Postwar policy concertation to early 1980 s; 1989 Common Course Agreement \\
\hline \multicolumn{2}{|r|}{ Medium concertation countries } \\
\hline Britain & Social Contract 1974-79 \\
\hline Ireland & Incomes policy agreements of 1970s; social pacts from 1987 \\
\hline Italy & $\begin{array}{l}\text { 1969-72 ‘conflict-negotiation' policy concertation; periodic social pacts from } \\
1978\end{array}$ \\
\hline Spain & Broad social pacts of late 1970 s and early 1980s; narrow social pacts $1994-97$ \\
\hline \multicolumn{2}{|r|}{ Low concertation countries } \\
\hline France & 1968 Grenelle Accords \\
\hline Germany & 1993 Solidarity Pact \\
\hline
\end{tabular}

Source: Berger and Compston 2002, country chapters.

If the theory is valid, we would expect that the historical record will show that the creation of broad policy concertation is preceded by a government perception that there is a relevant problem which current policy measures are failing to solve, at a time when there is already significant pre-existent agreement on the broad aims and mechanisms of economic policy (at a minimum, acceptance of both capitalism and collective bargaining) plus a pre-existent perception that there is a reasonable likelihood that any agreements struck will be implemented. The lack of any one of these is expected to prevent the coming into being of broad policy concertation.

The persistence of broad policy concertation is expected to be associated with the perceived problem being solved or disappearing, while a significant degree of economic agreement continues and the policy actors retain confidence in the likelihood of implementation of agreements. If the problem persists, policy concertation has failed and we would not expect policy concertation to continue. Neither would it be expected to persist if either of the other factors were absent.

Accordingly, termination of broad policy concertation is expected to be preceded either by failure to solve the relevant problem, or by the emergence of significant disagreement on economic policy, or the emergence of doubts about future implementation of agreements.

And the non-existence of broad policy concertation is expected to be associated with either the lack of a relevant problem, or lack of significant economic agreement, or doubts about the implementation of possible agreements. 
It can be seen that although the persistence or non-existence of broad policy concertation has to be hypothesised to be coincident with specific configurations of the independent variables, which makes it difficult to determine whether these configurations are causal factors or merely correlates of the dependent variable, changes in the dependent variable - creation or termination of broad policy concertation - are hypothesised to follow changes in the configurations of independent variables, consistent with these configurations being causal factors but not consistent with their being mere correlates of changes in the dependent variable. All claims in the following account about the consistency (or otherwise) of empirical observations with the configurational theory adhere rigidly to this rule.

\section{1945-late 1960s}

The entrenchment of broad policy concertation in Sweden and its establishment in Austria and the Netherlands during the two decades following the end of World War II can be readily explained in terms of the configurational theory.

In Sweden, alone among our nine countries, broad policy concertation had been established before the war. This can be explained in terms of the configurational theory by the fact that only in Sweden did a significant degree of economic agreement, one of the prerequisites for policy concertation according to the theory, come into being prior to World War II. After they came to power in 1932 in the midst of the Depression, the Social Democrats, who had shelved plans for nationalisation and accepted capitalism and the need for international competitiveness following their defeat in the 1928 'Cossack election', broadened the scope of the existing narrow policy concertation by instituting regular top-level negotiations between government and interest organisations and extending the representation of these organisations on the governing boards of the semi-autonomous administrative agencies that implement most public policy in Sweden. The bipartite Saltsjöbaden Agreement of 1938 demonstrated that employers and unions accepted each other's existence and legitimacy, while the high degree of organisation of Swedish employers and unions facilitated implementation of agreements.

After the war, during which broad policy concertation had continued, its existence was briefly threatened in the late 1940s by Social Democratic proposals for a planned economy, but these were dropped following the 1948 election and representatives of employers and trade unions were increasingly included in policy-making commissions, which aimed at reaching agreed positions on legislative proposals, and on the governing boards of administrative agencies. Between 1949 and 1955 ministers and civil servants met weekly with representatives of business, unions and farmers to discuss and arguably decide economic policy, and top-level consultation continued even after these weekly meetings ceased. This can be readily explained in terms of the configurational theory. The economic success of this period was attributed largely to the 'Swedish model' of which broad policy concertation was an integral part, meaning that it was perceived to have largely solved the problems which it was created to solve, and a common economic understanding had been established aimed at economic growth via allowing the capitalist economy to operate freely. In addition, all policy actors, including the unions, accepted the need for wage restraint. Finally, the inclusive and centralised nature of employer and union organisations meant that their leaders could deliver on implementation.

Moves in Austria towards broad policy concertation began early in the postwar period, when Soviet occupation of a third of the country contributed to a shared view that conflict had to be avoided. This meant acceptance of capitalism by trade unions and acceptance of unions and collective bargaining by employers. Employers also accepted economic planning and large-scale state 
intervention in the economy, including nationalisation of key industrial sectors. In addition, strong institutions capable of implementing agreements (the Chambers of Business and Labour, plus a single, centralised trade union confederation) were established (or re-established) between 1945 and 1947. However actual policy concertation was fitful until 1957, when concertation on a widening range of economic and social issues commenced in a temporary Parity Commission at a time of rising inflation, skilled labour shortages and strikes. By this time economic views had converged even further. The perceived success of the Parity Commission's initial economic program was followed by its being made permanent in 1963, which established policy concertation as the dominant policy-making style in Austria (see also Tálos and Kittel 1996).

The establishment in the Netherlands of a set of corporatist institutions designed in part as forums for policy concertation was largely motivated by the felt urgency of postwar reconstruction and preceded by growing shared economic understanding. Implementation was not seen as a serious problem. In 1950 the tripartite Social and Economic Council became the government's paramount advisor on economic and social questions: where recommendations were agreed, these were almost invariably accepted by the government. The common understanding of the aims and mechanisms of economic policy was based on the development during the war of a shared conviction that cooperative industrial relations, which implies the acceptance by all political actors of both capitalism and collective bargaining, was indispensable for postwar reconstruction, along with wage restraint and a prominent role for the government. As in Austria, the perceived success of the economic policy that emerged was followed by the entrenchment of broad policy concertation.

The lack of broad policy concertation in France, Italy, Germany and Ireland during this period can also be explained in terms of the configurational theory.

Although the postwar system of planning in France was supposed to have been based on tripartite concertation in institutions such as Planning Commissions, in fact it was state-driven and trade unions were marginalised. The tripartite Economic and Social Council designed to be consulted on draft social legislation also failed to operate as a forum for policy concertation. However the 1940s did see the establishment of social security funds managed jointly by employers and trade unions. The failure to establish broader policy concertation can be explained in terms of the theory by the domination of the trade union movement by communists, as this meant that a significant degree of shared economic understanding between governments, employers and unions, one of the preconditions for broad policy concertation, did not exist.

The lack of broad policy concertation in Italy during this period, despite the creation of institutions designed at least partly for this purpose, can also be explained by the lack of common economic understanding consequent on communists being powerful in the trade union movement. At the same time, however, a convention was established in the 1950s that all industrial relations legislation must be acceptable to both employers and unions (see also Ferner and Hyman 1992: 533, 540).

The failure of West German governments to introduce broad policy concertation during the two decades after 1945 can be explained in terms of the configurational theory mainly by doubts about the capacity of the peak union confederation DGB to deliver wage restraint in return: only its constituent unions were empowered to conduct wage bargaining but these unions were very resistant to any infringement of free collective bargaining. In addition, when the Federal Republic was established in 1949 new approaches were already being tried to tackle Germany's serious economic problems, namely the currency reform of 1948 and 'social market' ideas. Because it was not yet clear whether these policies would work, they could not be blamed for failing to cope with the economic problems, so another of the conditions for policy concertation was absent as well. By the 
early 1950s the postwar economic boom was under way, again leaving no incentive for the government to switch from existing modes of policy-making. Finally, until the mid-1950s there were considerable differences in economic views on issues such as nationalisation, planning and codetermination. Still, during the 1940s and 1950s regular and wide-ranging consultation was institutionalised at all levels (see also Hardach 1976: 158-60, Markovits : 1986, esp. p.27).

In Ireland the situation was to some extent conducive to policy concertation, as there were severe economic problems and the views of employers and trade unions were not as polarised as elsewhere. Its absence can be explained in terms of the configurational theory by the fact that confidence in the likelihood of implementation of any agreements reached was undermined by the continuing inability of trade unions to coordinate collective bargaining.

In relation to Britain, however, it is not clear that the configurational theory is wholly persuasive. The lack of postwar broad policy concertation in Britain during this period, despite considerable agreement on economic policy and the precedent of effective policy concertation during the war, can be explained in terms of the theory by the fact that expectations of implementation were undermined by the inability of the peak employer and union confederations to guarantee the compliance of their constituent organisations with any agreements reached at national level. Middlemas argues that shop-floor resistance prevented union agreement to wage restraint between 1950 and 1965. On the other hand, union agreement to the 1948-50 wage freeze suggests that implementation problems did not rule out policy concertation at that time, which means that its absence is problematic for the configurational theory. Employers and unions did gain representation on a host of consultative and advisory committees during this period. In the mid-1960s the perceived failure of British economic policy, combined with a shared perception that French indicative planning was a success, led to the establishment of the tripartite National Economic Development Council in 1962 to set targets for production and influence pay awards, but this remained consultative only. An apparent window of opportunity in the mid-1960s for the government to exchange policy concertation for wage restraint coincided with an upsurge of shop floor militancy, and was closed shortly thereafter when an attempt by the Labour government to extend legal regulation to trade unions and collective bargaining led to serious conflict with the unions (see also Middlemas 1979: 405, 410, 433-44, Clegg 1994: 427).

\section{The late 1960s to late 1980s}

After the relative calm and economic prosperity of the two decades following World War II, the next two decades were more troubled. One result was the appearance of broad policy concertation in several countries in which it had been mostly or wholly absent - Britain, France, Ireland, Italy and Spain - at the same time as its efficacy was coming into question in two of the three countries in which it had been most important: the Netherlands and Sweden. In Austria, broad policy concertation in the form of the Social Partnership continued, while in Germany it continued to be non-existent despite the prominence of elaborate consultative mechanisms such as Concerted Action. Almost all of these developments can be explained in terms of the configurational theory. ${ }^{3}$

The lack of policy concertation under the 1970-74 Conservative government in Britain, despite attempts to negotiate agreements in the latter part of this period, can be explained by lack of a common economic understanding, as the Conservatives viewed trade unions as obstacles to good economic management and were seeking to limit their power via legislation. The economic views of the Labour government elected in 1974, which did not continue the attempts to regulate industrial relations that had poisoned relations with the unions in the 1960 s, were considerably closer to those of the unions. While the high inflation of the early 1970s constituted a problem for which policy 
concertation was an obvious possible solution, the establishment of broad policy concertation in 1974 in the form of a Social Contract between the government and unions is somewhat problematic for the configurational theory in that there was little confidence at the time in the ability of union leaders to deliver wage restraint in return for policy concertation. In the event, however, the unions did deliver a considerable degree of wage restraint up to 1978, when union leaders were unable to secure the acceptance by their members of the latest agreement, resulting in the industrial action of the so-called Winter of Discontent of 1978-79. However it should be noted that another agreement was signed in early 1979, so that broad policy concertation in Britain was not in fact terminated until after the Conservatives returned to power in May 1979 with an economic policy that denied the utility and legitimacy of trade unions and collective bargaining.

Policy concertation in France took a completely different and unexpected path, and one that does not fit the configurational theory. Despite a continuing lack of shared economic understanding between the government and employers, on the one side, and unions, on the other, the events of May 1968 led to efforts by Prime Minister Pompidou and employers to secure an end to the biggest wave of strikes and demonstrations in $20^{\text {th }}$ century French history by negotiating the so-called Grenelle Accords with the trade unions. (This pattern of massive social unrest followed by a negotiated agreement is similar to the sequence of events leading up to the Matignon Agreement of June 1936.) Although in 1968 the subsequent agreement with the unions was not actually signed by the union leaders, its contents having been rejected by the rank and file, which illustrates the inability of French trade unions to deliver their sides of agreements, the Gaullist government still implemented its provisions on increasing the minimum wage and reducing social security charges. Occupations and barricades continued in the first half of June but then faded away, and no more policy concertation took place (see also Bernstein 1993: 218-219). In fact no real broad policy concertation took place for the remainder of the period despite the occurrence of high-profile 'summits' from time to time. This lack of concertation is in line with the prediction of the configurational theory that a lack of shared economic understanding, and doubts about the implementation capacity of one or more policy actors, prevents the occurrence of broad policy concertation.

The massive social unrest of the late 1960s in Italy also led to broad policy concertation despite not only a lack of shared economic understanding among the policy actors but also a persistent lack of government implementation of the resultant agreements. Labour unrest beginning in 1968 included a national strike to demand higher pensions, which were granted in February 1969. Between 1969 and 1972 further massive strikes, rallies and marches in support of reform proposals led via negotiation to rights at the workplace being guaranteed by law in the Workers' Charter of May 1970, plus agreements between the unions and the government on tax, housing, health, education, transport, and investment in the South, but these were seldom properly implemented by the government. Unions were also given seats on an increasing number of administrative agencies in economic and social areas. Once labour militancy started to subside after 1972, however, significant policy concertation came to an end (see also Ginsborg 1988: 309-331, Barkan 1984: 68-97, Regini 1980).

In 1977 policy concertation resumed, this time in response to economic problems, and continued on and off for the next two decades. At first its scope was rather narrow - agreements on industrial restructuring and youth unemployment in 1977, and on training and pensions in 1978 - but in 1983 a broad social pact was agreed that covered tax and government charges, employment, health, social welfare and development of the South. In 1984 the trade union movement split over whether to accept a package involving policy concessions in exchange for cuts in wage indexation, but narrower agreements on tax, pensions, employment and the minimum wage were reached in the second half of the decade. The rise of broad policy concertation in the late 1970s and early 1980s 
can be explained in terms of the configurational theory in that this coincided with a worsening of the economic situation, a broadening of the area of shared economic understanding after the unions accepted the need for wage restraint and labour flexibility in the late 1970s, and improved chances of implementation due to the increased unity of the union movement. On the other hand, the configurational theory would predict that low expectations of government implementation of its side of bargains, based on its poor record in this respect, would deter unions from participating in policy concertation, but instead we see repeated attempts to reach agreements. Although union doubts about the prospects of adequate government implementation were a factor in the breakdown of broad policy concertation in 1984, it is generally agreed that the main cause of its collapse was the extension to the trade union movement of party rivalry between the Socialists (supported by the Christian Democrats) and the Communists (see also Ferner and Hyman 1992: 541-542).

In short, the cases of France in 1968 and Italy during this whole period are somewhat anomalous from the point of view of the configurational theory. A possible partial explanation is that the problem that motivated broad policy concertation in both France and Italy in the late 1960s, massive social unrest, was rather different to the economic problems prominent elsewhere where broad policy concertation took place. In other words, the causal dynamics of broad policy concertation may be different where social unrest is the relevant problem, so that the configurational theory does not apply.

The remaining countries do fit the configurational model.

In Ireland, economic problems had persisted throughout the postwar period but it was not until the economic views of governments, employers and trade unions converged somewhat, and centralised collective bargaining simplified the problem of implementing wage agreements after 1970, that policy concertation emerged when the government began to facilitate annual wage agreements by offering budgetary concessions. The agreements of 1977 and 1978 were explicitly tripartite in nature, and the National Understandings of 1979 and 1980 contained separate sections for wages and public policy. However the persistence of economic problems led to disillusionment with the new system and, in accord with the predictions of the configurational theory in such circumstances, broad policy concertation came to an end in 1982, the precipitating event being a change of government.

Spain's situation in the postwar period was fundamentally different to that of the other nine countries in that it was only after Franco's death in 1975 that the country moved towards democracy. Nevertheless, the social pact based policy concertation that emerged after 1975 can be explained in terms of the configurational theory. First, not only were there economic problems to motivate consideration of broad policy concertation, but also a fear of a reversion to dictatorship that led the political actors to take great care to avoid social unrest. This meant serious efforts to reach agreement on controversial issues, including public policy issues. Second, the area of shared economic understanding was much greater than when policy concertation had last been tried in the 1930s, and included agreement on the need for wage restraint. This period of broad policy concertation came to an end in the early 1980s following implementation problems plus a divergence of economic views as the government and employers, but not unions, displayed increased interest in deregulation. At the same time the solidification of Spanish democracy removed the fear of a return to authoritarian rule.

Meanwhile the Austrian Social Partnership continued to thrive on economic success. However policy concertation in both the Netherlands and Sweden ran into trouble during the 1970s as new economic problems arose and the economic views of employers, unions and governments diverged. 
In the Netherlands, the economic views of employers and unions were diverging by the end of the 1960s, with employers taking a more laissez-faire line while unions demanded industrial democracy. By the 1970s the Social and Economic Council was no longer able to deliver meaningful unanimous recommendations to the government: policy concertation was paralysed, and from 1982 the government deliberately bypassed the Council for economic advice. Although the bipartite Wassenaar Accord of the same year led to increased employer-union cooperation, and over the next decade a measure of economic agreement reappeared at a time when economic difficulties continued to be severe, an attempt at resuming broad policy concertation in 1989 with the Common Course Agreement was not sustained because employers did not believe that the terms of the Agreement had been adequately implemented, and refused to enter into new negotiations.

In Sweden, the economic views of the political actors had started to diverge in certain areas as early as the late 1950s, and growing union radicalism culminated in the 1970s with the Meidner Plan's proposal gradually to transfer ownership of industry from private capital to union-controlled investment funds. This was interpreted by employers as a deadly threat, and in the 1980s they moved towards a neo-liberal economic position and began a massive ideological counterattack even though the watered-down version of the Meidner Plan that was eventually legislated did not pose any threat to capitalism in Sweden. In the meantime the Social Democratic governments of the 1980s increasingly came into conflict with the unions on economic policy. By the late 1980s ideological polarisation had led to virtual deadlock in policy concertation.

As indicated earlier, the absence of policy concertation in postwar Germany can be explained in terms of the configurational theory not only by the relative economic success of the 1950s and early 1960 s but also by the inability of the peak union confederation to deliver wage restraint due to its lack of authority over wage bargaining coupled with strong member resistance to any interference in free collective bargaining. The continuing strength of this resistance was made quite clear by the wildcat strikes of 1969, and its persistence explains the lack of broad policy concertation in Germany during this period. Although the economic situation deteriorated in 1966, and the area of shared economic understanding between the policy actors broadened once the Social Democrats replaced the anti-union FDP in government with the Christian Democrats the same year, the socalled 'Concerted Action' established in 1967, which lasted until 1977, did not constitute policy concertation, despite its name, because agreements on public policy were not part of its remit. In addition, the new government's application of Keynesian techniques in the mid-1960s was followed by a resurgence of economic growth, reducing the incentive to engage in policy concertation. The more serious economic problems of the 1970s and 1980s were addressed by a turn to austerity rather than to policy concertation, reducing the area of shared economic understanding with the unions (see also Markovits 1986: 116-117).

\section{From the late 1980 s to 1997}

Developments in policy concertation during the decade since 1987 can without exception be explained in terms of the configurational theory.

The three countries in which policy concertation was most important during this period were Austria, Ireland and Italy.

Although the relevance of the Social Partnership for decision-making in Austria declined somewhat, it remained important in many policy areas right up to 1997. This persistence of broad policy concertation occurred in the context of an economic performance that compares favourably with 
most other West European countries, plus continued broad consensus on the aims of economic policy and continued consistent implementation.

The resumption of broad policy concertation in Ireland in 1987, in the form of the first of a series of three-year tripartite agreements with provisions on a wide range of public policy, is also in line with the theory: Ireland's economic problems had not been solved by terminating policy concertation in 1982 while the shared understanding of the aims and mechanisms of economic policy had broadened further during the 1980s and now included agreement on the need for wage restraint. Implementation does not appear to have been seen as a serious problem. Since 1987 broad policy concertation has become well-established in a variety of different forums as the country has experienced an unprecedented period of economic success.

The resurgence of social pact based policy concertation in Italy during the early 1990s can also be readily explained: economic problems were joined by political crisis at the same time as the views of the political actors converged further on a common understanding of economic objectives and mechanisms, while potential implementation problems were reduced by improvements in the capacity of the Italian government to deliver on commitments made, plus increased cooperation among the three trade union confederations. The persistence of periodic broad policy concertation during this period has been accompanied by a widespread view that Italy's substantial progress in tackling its economic problems in recent years can be at least in part attributed to the social pacts of 1992, 1993 and 1995.

In most of the other six countries, policy concertation was restricted mainly to employment and social policy.

Since the failure of the tripartite Common Course agreement of 1989, the prospects for further broad policy concertation in the Netherlands have been impeded by continuing disagreement over economic and social policy plus the fact that the abandonment of broad policy concertation has been accompanied by considerable economic success.

In Sweden, decades of policy concertation in the form of organisational representation in the decision-making of administrative agencies came to an end in 1992 when the centre-right Bildt government replaced union representatives with lay members selected, at least officially, for their expertise. This followed the unilateral withdrawal of employer representatives in 1991. The only significant policy-making institutions in which this de-concertation process did not occur were pension funds and the Labour Market Board. Other forms of broad policy concertation had already come to an end. From the perspective of the configurational theory this development is hardly surprising, as broad policy concertation had already been virtually paralysed by the divergent economic views of employers and unions, with employers increasingly criticising the economic role of trade unions and collective bargaining even after the unions drew back from their radicalism of the 1970s and early 1980s. However it was not until the arrival of an economic crisis in the early 1990s, which policy concertation had been unable to prevent, plus the election of a government that saw unions and collective bargaining as an obstacle to economic recovery, that the coup de grace was delivered.

In Germany, on the other hand, where policy concertation had been restricted to certain areas of social insurance, labour law and health, the severe economic and social problems created by reunification led to short-term broad policy concertation in the form of the 1993 Solidarity Pact. What appears to have happened here, viewed through the prism of the configurational theory, is that union opposition to interference in free collective bargaining was temporarily lessened in the face of such an obvious national crisis, thus briefly removing the constraint that had blocked the 
establishment of broad policy concertation in previous years. Once the immediate crisis was past, however, this opposition to including wage restraint in negotiations with the government reasserted itself.

In Spain, the broad social pacts of the late 1970s and early 1980s were not repeated, following disillusionment with their poor implementation in a context of continuing disagreement on economic policy, although major reforms to labour law and social security were accomplished by a number of social pacts between 1994 and 1997 that included the government either as a formal participant or as the author of legislation needed to implement their policy contents.

In France, governments, employers and trade unions still lack a shared understanding of the goals and mechanisms of economic policy, and policy concertation remains restricted to social security and labour law.

There was just one country in which no policy concertation of any sort occurred: Britain, where all forms of policy concertation were extinguished by the vehemently anti-union Conservative government of 1979-1997. Although the economic views of the new Labour government in 1997 were substantially closer to those of the unions, the economic upturn that took place during the late 1990s meant that there was no impetus to switch policy-making styles. In addition, the memory of the Winter of Discontent maintains the view that trade unions would have problems implementing their side of any bargains.

\section{CONCLUSION}

The configurational theory of policy concertation posits that the incidence of broad policy concertation between governments, employers and unions is a function of the specific configurations of just three variables: perceived problems, the degree of pre-existent shared economic understanding between policy actors, and their expectations in relation to implementation. The results of the above survey of nine West European countries between 1945 and 1997 substantially confirm this view. There are just a handful of cases of broad policy concertation (or its absence) that are not adequately explained: Britain during the late 1940s and in 1974, France in 1968, and Italy during the period 1967-84.

Further work is obviously needed if a theory with one hundred per cent explanatory success is to be constructed, but in the meantime the substantial explanatory success of the configurational theory means that it constitutes a powerful device for understanding the causal dynamics of policy concertation. No other theory of policy concertation has such explanatory power in relation to so many countries over such a long period of time. 


\section{REFERENCES}

Barkan, J. (1984). Visions of emancipation: the Italian workers' movement since 1945. New York: Praeger.

Berger, S., and Compston, H., eds. (2002). Policy concertation and social partnership in Western Europe: Lessons for the $21^{\text {st }}$ century. Oxford: Berghahn.

Bernstein, S. (1993). The Republic of De Gaulle, 1958-1969. Cambridge: Cambridge University Press.

Calmfors, L. (1993). Centralisation of wage bargaining and unemployment - a survey. OECD Economic Studies 21: 161-191.

Cameron, D. (1984). Social democracy, corporatism, labour quiescence and the representation of economic interests in advanced Western society, in J. Goldthorpe (ed.), Order and conflict in contemporary capitalism. Oxford: Oxford University Press.

Clegg, H. (1994). A history of British trade unions since 1889, Vol.3, 1934-1951. Oxford : Clarendon Press.

Compston, H. (1995). Union participation in economic policy-making in France, Italy, Germany and Britain, 1970-1993. West European Politics 18: 314-339.

Compston, H. (1998). The end of national policy concertation? Western Europe since the Single European Act. Journal of European Public Policy 5: 507-526.

Compston, H. (2002). Introduction: The strange persistence of policy concertation, in S. Berger and H. Compston (eds.). Policy concertation and social partnership in Western Europe: Lessons for the $21^{\text {st }}$ century. Oxford: Berghahn.

Crepaz, M. (1992). Corporatism in decline? An empirical analysis of the impact of corporatism on macroeconomic performance and industrial disputes in 18 industrialized democracies. Comparative Political Studies 25: 139-168.

Crouch, C. (1993). Industrial relations and the European state tradition. Oxford: Clarendon Press.

Ferner, A., and Hyman, R. (1992). Italy: Between political exchange and micro-corporatism, in A. Ferner and R. Hyman (eds.), Industrial relations in the new Europe. Oxford: Blackwell.

Ginsborg, P. (1988). A history of contemporary Italy. London: Penguin.

Hardach, K. (1976), The political economy of Germany in the twentieth century. Berkeley: University of California Press.

Keman, H., and Pennings, P. (1995). Managing political and societal conflict in democracies: Do consensus and corporatism matter? British Journal of Political Science 25: 271-281.

Kingdon J. (1995). Agendas, alternatives and public policies, 2nd edition. New York: HarperCollins.

Lehmbruch, G. (1979). Liberal corporatism and party government, in P. Schmitter and G. Lehmbruch (eds.), Trends towards corporatist intermediation. London: Sage.

Lijphart, A., and Crepaz, M. (1991). Corporatism and consensus democracy in eighteen countries: conceptual and empirical linkages. British Journal of Political Science 21: 235-256. 
Markovits, A. (1986). The politics of the West German trade unions. Cambridge: Cambridge University Press.

Middlemas, K. (1979). Politics in industrial society. London: André Deutsch.

Olson, M. (1982). The rise and decline of nations. New Haven: Yale University Press.

Regini, M. (1980). Labour unions, industrial action and politics, in P. Lange and S. Tarrow (eds.), Italy in transition: Conflict and consensus. London: Frank Cass.

Schmitter, P. (1979). Still the century of corporatism? in P. Schmitter and G. Lehmbruch (eds.), Trends towards corporatist intermediation. London: Sage.

Siaroff, A. (1999). Corporatism in 24 industrial democracies: Meaning and measurement. European Journal of Political Research 50: 175-205.

Slomp, S. (1992). European labor relations and the prospects of tripartism, in T. Treu (ed.), Participation in public policy-making: The role of trade unions and employers' associations. Berlin and New York: Walter de Gruyter.

Tálos, E., and Kittel, B. (1996). Roots of Austro-Corporatism: Industrial preconditions and cooperation before and after 1945, in G. Bischof and A. Pelinka (eds.), Austro-Corporatism: Past, present, future. New Brunswick and London: Transaction Publishers.

Woldendorp, Jaap (1997). Neo-corporatism and macroeconomic performance in eight small West European countries (1970-1990). Acta Politica 32: 49-79. 


\section{NOTES}

${ }^{1}$ This article develops the theory first set out in my final chapter in Berger and Compston 2002. I gratefully acknowledge the financial support given by the European Commission for this project, and the useful comments of three anonymous referees.

${ }^{2}$ The countries examined, and the authors of the historical and political chapters respectively, are Austria (Jill Lewis, and Bernhard Kittel and Emmerich Talos), Britain (Chris Williams and Peter Dorey), France (Susan Milner and Nick Parsons), Germany (Stefan Berger and Jeremy Leaman), Ireland (Emmet O'Connor, and Damien Thomas and Rory O'Donnell), Italy (Gino Bedani and Bruce Haddock), the Netherlands (Anton Hemerijck and Hans Slomp), Spain (Robert Robinson and Miguel Martinez Lucio), and Sweden (James Fulcher and Victor Pestoff).

${ }^{3}$ Information in this and the following section is also drawn from Compston 1995. 